\title{
A new species of pentastomida infecting Tropidurus hispidus (Squamata: Tropiduridae) from Caatinga in Northeastern Brazil
}

\author{
Almeida, WO. ${ }^{\mathrm{a} *}$, Freire, EMX. ${ }^{\mathrm{b}}$ and Lopes, $S \mathrm{G}^{\mathrm{a}}$ \\ aDepartamento de Ciências Físicas e Biológicas, Universidade Regional do Cariri, \\ Rua Cel. Antônio Luiz, 1161, CEP 63105-000, Crato, CE, Brazil

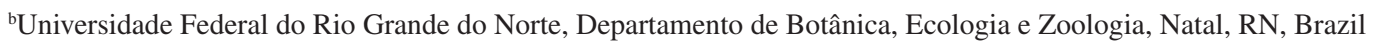 \\ *e-mail: walmeida@urca.br
}

Received June 19, 2006 - Accepted August 18, 2006 - Distributed February 29, 2008

(With 4 figures)

\begin{abstract}
This article describes a new species of Brazilian Raillietiella Sambon, 1910 from lungs of Tropidurus hispidus (Spix, 1825). Between July and October 2005 eighteen specimens of T. hispidus were actively captured with elastic rubber slings in granite outcrops (lajeiros) ( $06^{\circ} 59^{\prime} \mathrm{S}$ and $39^{\circ} 31^{\prime} \mathrm{W}$ ) from caatinga formations in the municipality of Farias Brito, State of Ceará, Northeastern Brazil. One female and one male of T. hispidus had lungs infected by Raillietiella mottae sp. nov. (prevalence $11.1 \%$ and mean intensity of infection $6.0 \pm 1.4$, range 5-7). The parasite's main diagnostic characteristics include the dimensions of sharp hooks and strongly curved or "C-shaped" male copulatory spicules with knob-like posterior projection from the base towards the inner curvature of the spicule.
\end{abstract}

Keywords: Endoparasites, Lizards, Raillietiella, neotropical region.

\section{Uma nova espécie de Pentastomida infectando Tropidurus hispidus (Squamata: Tropiduridae) da Caatinga na região Nordeste do Brasil}

\begin{abstract}
Resumo
Este artigo descreve uma nova espécie de Raillietiella Sambon, 1910 a partir dos pulmões de Tropidurus hispidus (Spix, 1825). Entre julho a outubro de 2005, dezoito espécimes de T. hispidus foram coletados ativamente usando-se estilingues em formações rochosas (lajeiros) $\left(06^{\circ} 59^{\prime} \mathrm{S}\right.$ e $\left.39^{\circ} 31^{\prime} \mathrm{W}\right)$ no domínio da caatinga no município de Farias Brito, estado do Ceará, nordeste do Brasil. Uma fêmea e um macho de T. hispidus tinham seus pulmões infectados por Raillietiella mottae sp. nov. (prevalência $11,1 \%$ e intensidade média de infecção 6,0 $\pm 1,4$, amplitude 5-7). As principais características diagnósticas dos parasitas incluem as dimensões dos ganchos com ponta aguda e as espículas copulatórias curvadas ou "em forma de C", com base posterior em forma de maçaneta, cuja parte distal é direcionada para o interior da curvatura da espícula.
\end{abstract}

Palavras-chave: Endoparasitas, Lagartos, Raillietiella, região neotropical.

\section{Introduction}

Raillietiella constitutes one of the pentastomid groups that infect the respiratory tract of South American amphisbaenids, lizards, and snakes. About 40 species of raillietiellids have been described in the world, but the Neotropical diversity of pentastomids has not received much academic attention and remains poorly known (Almeida and Christoffersen, 1999; 2002). An attempt to survey the genus Raillietiella in Brazil generated only three recorded species: $R$. freitasi (Motta and Gomes, 1968), R. furcocerca (Diesing, 1863) and R. gigliolii Hett, 1924. The latter two species are parasites of serpents and amphisbaenids, respectively. Raillietiella freitasi is the single pentastomid species that infects the lizards Mabuya punctata (Spix, 1825) and Tropidurus torquatus (Wied, 1820). Both host species were captured on the island of Fernando de Noronha (Motta, 1963; Motta and Gomes, 1968; Rego, 1983, 1984).

Rallietiellids infecting lizards in Brazilian continental ecosystems were firstly recorded by Vrcibradic et al. (2002) and Dias et al. (2005). Vrcibradic et al. (2002) reported only larvae of Raillietiella sp. in the lungs of skink Mabuya agilis (Raddi, 1823) collected from the restinga ecosystems in the states of Rio de Janeiro and Espirito Santo. Dias et al. (2005) reported a likely new species of Raillietiella aff. furcocerca infecting the lungs of two whiptail lizard species, Cnemidophorus abaetensis Dias, Rocha and Vcribradic, 2002 and Cnemidophorus 
ocellifer (Spix, 1825) also in a restinga habitat in the state of Bahia.

This article describes a new species of Brazilian Raillietiella infecting lungs of the lizard Tropidurus hispidus (Spix, 1825). Ecological data about prevalences and mean intensity of infection were also estimated here.

\section{Material and Methods}

Between July and October 2004, active capture of lizards was carried out by using rubber slings. These animals were collected from granite outcrops (locally known as "lajeiros"), where a typical caatinga vegetation occurs (with thorny stunted trees and cactuses), located at $06^{\circ} 59^{\prime} \mathrm{S}$ and $39^{\circ} 31^{\prime} \mathrm{W}$ in the municipality of Farias Brito, in the state of Ceará, Northeastern Brazil. The collection site is situated in a semi-arid area with hot climate, mean temperature range from $26-28{ }^{\circ} \mathrm{C}$ and annual mean rainfall is $896.50 \mathrm{~mm}$, with a rainy period extending from January to April. The vegetation in the collection site had been extensively cut down to be used in many coal-fired industrial and agroindustrial activities (IPECE, 2005).

Immediately upon collection, the animals were euthanized with ether and their snout-vent length (SVL) measured with a caliper (to the nearest $0.1 \mathrm{~mm}$ ). The lizards were fixed and preserved in ethanol 70\%. They were subsequently identified according to Vanzolini et al. (1980) and Rodrigues (1987).

Eighteen specimens of Tropidurus hispidus were collected: fourteen females (mean SVL $=79.1 \pm 4.7 \mathrm{~mm}$; range 61-117 mm), and four males (mean $\mathrm{SVL}=86.6 \pm$ $10.9 \mathrm{~mm}$; range $60-100 \mathrm{~mm}$ ). After the preservation treatment, they were deposited in the vertebrate collection of the Universidade Regional do Cariri LZ-URCA (0091, 0092, 0130-0135, 0156-0164, 0197-199).

The respiratory tracts of the lizards were removed and the search for pentastomids was carried out under a stereomicroscope. The pentastomids collected were cleared in Hoyer's medium, temporary slide-mounted and preserved in ethanol $70 \%$. Identification is based on the dimensions of the hooks and of the copulatory spicule of males by using a microscope with a micrometric eyepiece (see Ali et al., 1984, 1985). Figures were made with a drawing tube connected to a brightfield microscope. We also compared the specimens with material provided by the Helminthological Collection of the Oswaldo Cruz Institute (CHIOC): Raillietiella freitasi (20420, 20421, 20429, 20431, 20432, 20434, 20439, 30325a-c, 30326, 30327, 30328, 30329a-c, 30330a-b), and material deposited in the Zoological Collection of the Universidade Regional do Cariri (LZ-URCA): Raillietiella gigliolii (0099-0101). Eco-parasitological terms used in this study followed Bush et al. (1997).

\section{Results}

Among the 18 specimens of Tropidurus hispidus examined, one female and one male (prevalence $11.1 \%$ ) had their lungs infected by a new species of Raillietiella with mean intensity of infection $6.0 \pm 1.4$, range 5-7. We noticed that the pentastomids collected were adults because of their simple hooks with no chitinous accessories, in opposition to nymphs, which have double hooks and chitinous accessories (Riley, 1986). This is the first record of pentastomids infecting a specimen of T. hispidus.

The diet observed in the captured tropidurids was essentially carnivorous (ants and termites) and insects are probable intermediate hosts, as happens with other species of insectivorous lizards (Ali et al., 1985: 116; Riley, 1993: 300).

\subsection{Raillietiella mottae sp. nov. (Figures 1-4)}

Description and measurements based on the holotype female and male and female paratypes (mounted in toto).

Female: body cylindrical, tapered posteriorly (claviform) (Figure 1), total body length $7.45 \pm 0.13 \mathrm{~mm}$ (7.2-7.8); buccal cadre sclerotized and thick-framed, lateral prongs not connected anteriorly (Figure 2), the cadre ends with cone-like projections; hooks arranged in a trapezoidal formation, simple, sharp blades with pointed tips, anterior hook with AB $122 \pm 1.00 \mu \mathrm{m}(120-15)$ and BC $222.5 \pm 0.96 \mu \mathrm{m}(220-224)$; posterior hook much larger with $\mathrm{AB} 225.5 \pm 0.48 \mu \mathrm{m}(224-226)$ and $\mathrm{BC}$ of $363.3 \pm 1.18 \mu \mathrm{m}$ (360-365); apical and dorsal papillae present and prominent; cephalothorax trapezoidal, distinct from abdomen, rostrum prominent with mouth terminal; abdomen with indistinct annuli; parapodial lobes present; anus ventral; caudal papillae present; uterus, straight and tube-like, opening anteriorly.

Male: with similar morphology to that of the female; body cylindrical, widest in anterior half of abdomen, total body length $3.7 \pm 0.26 \mathrm{~mm}$ (3.5-4.3), hooks simple, sharply pointed (Figure 3), anterior hook with $\mathrm{AB}$ $73 \pm 1.00$ (72-75) $\mu \mathrm{m}$ and BC $102 \pm 1.00 \mu \mathrm{m}$ (100-103); posterior hook much larger with $\mathrm{AB} 190.6 \pm 0.33 \mu \mathrm{m}$ (190-191) and BC $286 \pm 3.00 \mu \mathrm{m}$ (280-289); apical and dorsal papillae present and prominent; cephalothorax trapezoidal, distinct from abdomen, rostrum not prominent, with mouth terminal; abdomen with indistinct annuli; parapodial lobes present; apical and dorsal papillae present and conspicuous; copulatory spicules are strongly curved or "C-shaped" with knob-like projection from the base towards the inner curvature of the spicule (Figure 4); anus ventral; caudal papillae present; testis single, rounded, opening anteriorly.

Type specimens: Holotype $q$ LZ-URCA no. 0201; paratypes + LZ-URCA no. 202-205, ๙ $\curvearrowright$ LZ-URCA 206-212 ( $=12)$; all preserved in ethanol $70 \%$.

Type host: Tropidurus hispidus (Spix, 1825) distributed in all North and Northeast regions of Brazil (Rodrigues, 1987).

Site of infection: lungs.

Type locality: from caatinga $\left(06^{\circ} 59^{\prime} \mathrm{S}\right.$ and $\left.39^{\circ} 31^{\prime} \mathrm{W}\right)$, municipality of Farias Brito, State of Ceará, Northeastern Brazil. 

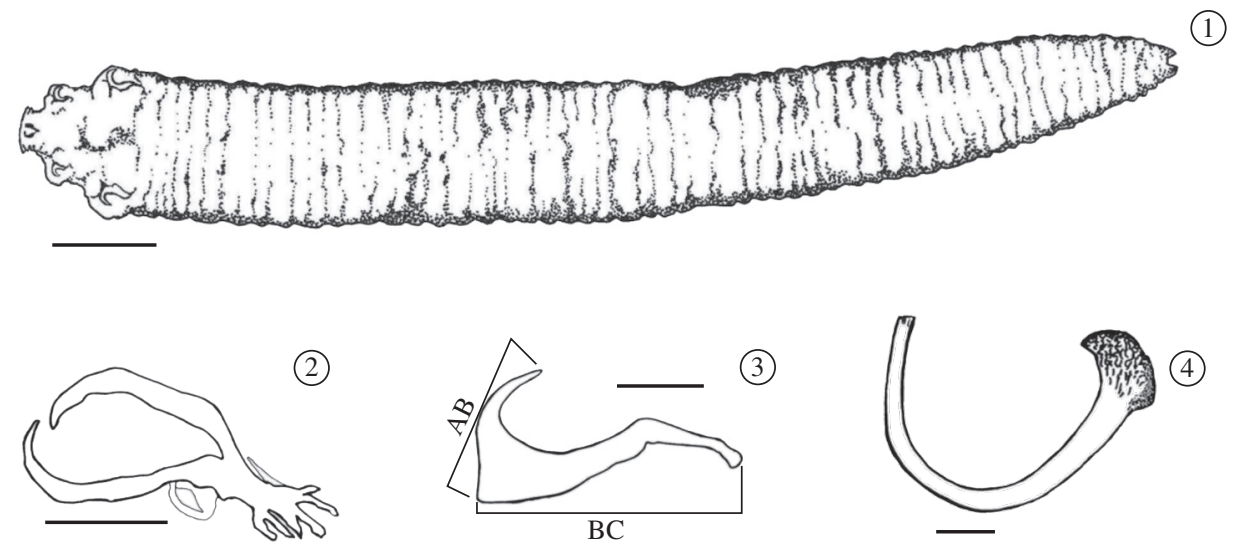

Figures 1-4. Raillietiella mottae sp. nov.: 1) entire female holotype (LZ-URCA no. 0201) viewed ventrally with sharply tip pointed hooks (scale bar $=0.78 \mathrm{~mm}) ; 2)$ buccal cadre of the female paratype (LZ-URCA 0202) $($ scale bar $=0.03 \mathrm{~mm}) ; 3)$ posterior hook dimensions measured: AB, blade length and BC, shank length (male paratype LZ-URCA 0206) (scale bar = $0.04 \mathrm{~mm}$ ); and 4) copulatory spicules with tips curved or "C-shaped" knob-like projection base of male paratype (LZ-URCA $\mathrm{n}^{\circ}$ 0207) (scale bar $\left.=0.39 \mathrm{~mm}\right)$.

Etymology: this species is named after Catarina da Silva Motta (Instituto Oswaldo Cruz) who made pioneer contributions to the taxonomy of the pentastomid endoparasites of Brazilian lizards.

\section{Remarks}

Raillietiella mottae is the second species of pentastomid parasite of lizards that has been described in Brazil. This species possesses superficial similarities with Raillietiella cartagenensis Ali, Riley and Self, 1985 (parasite of gekkos from Colombia), because they have sharp hooks and curved shafts in copulatory spicules. However, these spicules have a slightly flared base in $R$. cartagenensis (Ali et al., 1985: 115, Figure 1d) that differs completely from the one found it in $R$. mottae, which has a knob-like projection from the base towards the inner curvature. The dimensions of the hooks and morphology of the male copulatory spicules of $R$. mottae also distinguish this species from all other raillietiellid species described for the Neotropical Region (R. freitasi, $R$. furcocerca, and $R$. gigliolii) and the raillietiellid species with sharp hooks from small lizards of the world ("group I" sensu Ali et al., 1985) (Table 1).

\section{Discussion}

Rego (1983) identified a variation in the hooks from the specimens of the Raillietiella freitasi: some had blunt-posterior hooked tips (parasites of lizards) and other specimens had sharp-posterior hooked tips (parasites of amphibians). These last specimens were re-identified as Raillietiella bufonis Ali, Riley and Self, 1982, and thus $R$. freitasi have only blunt posterior hooks ("group II" sensu Ali et al., 1985). The male copulatory spicules of $R$. freitasi are rounded, club-shaped spicules which have the thickened bases on the inner curvature. Raillietiella mottae have completely different characters: posterior hooks with sharp tip ("group I" sensu Ali et al., 1985) and male copulatory spicules unique among all the raillietiellids: they are "C-shaped", with a knob-like projection from the base towards the inner curvature.

Despite the similarity in gross morphology between spicules of $R$. mottae and $R$. cartagenensis, which are restricted to the curvature, their bases are completely different. Perhaps the similarity in the curvature of the spicules is the result of a close phylogenetic relationship between those two species.

Pentastomids are endoparasites which have specificity for their hosts. Self and Kuntz (1967) pointed out that host-parasite interactions result from a long evolutionary association, and Riley (1986) supposed that approximately $50 \%$ of all pentastomid species are specific for a single host. Thus several new species should be described because of this specificity. Tropidurus hispidus is a new record of lizard host not related before with any pentastomid species. This reinforces the morphologic evidences presented in this study that $R$. mottae is a new species. Additionally, the collection of first pentastomid host specimens in the middle of the caatinga environment from Northeast Brazil also supports the morphologic data that $R$. mottae constitutes a new species. Certainly $R$. mottae is the second Brazilian pentastomid species among many other new species that still will be described as parasites of small lizards.

Acknowledgments - We thank to Dr. Dely Noronha, curator of the Helminthological Collection of the Oswaldo Cruz Institute - CHIOC, for the loan of pentastomid material. The authors gratefully acknowledge financial support, as a research grant received from Fundação Cearense de Apoio 
Table 1. Comparative characteristics of raillietiellids with sharp-tipped hooks. These pentastomids infect insectivorous lizards in the world (from Ali et al., 1985 and Abreu-Acosta et al., 2005, except “* species" described in this study).

\begin{tabular}{|c|c|c|c|c|c|c|}
\hline \multirow[t]{3}{*}{ Species } & \multicolumn{3}{|c|}{ Female } & \multirow{3}{*}{$\begin{array}{c}\text { Male } \\
\text { Length } \\
(\mathrm{mm})\end{array}$} & \multirow[t]{3}{*}{ Locality } & \multirow[t]{3}{*}{ Hosts } \\
\hline & \multirow{2}{*}{$\begin{array}{l}\text { Length } \\
(\mathrm{mm})\end{array}$} & \multicolumn{2}{|c|}{ Posterior hook $(\mu \mathrm{m})$} & & & \\
\hline & & $\mathbf{A B}$ & BC & & & \\
\hline $\begin{array}{l}\text { R. aegypti Ali, } \\
\text { Riley and Self } 1982\end{array}$ & $23-26$ & $\begin{array}{l}245 \\
(235-265)\end{array}$ & $\begin{array}{l}385 \\
(365-410)\end{array}$ & $<11$ & Egypt & $\begin{array}{l}\text { Agama stellio } \\
\text { (Linnaeus, 1758), } \\
\text { A. mutabilis Merrem, 1820, } \\
\text { Eumeces schneideri Daudin, } \\
\text { 1802, Uromastyx aegyptia } \\
\text { (Forskål, 1775) }\end{array}$ \\
\hline $\begin{array}{l}\text { R. amphiboluri } \\
\text { Mahon, } 1954\end{array}$ & $20-44$ & $\begin{array}{l}208 \\
(200-220)\end{array}$ & 370 & $8-12$ & Australia & $\begin{array}{l}\text { Amphibolurus barbatus } \\
\text { Glauert, } 1952\end{array}$ \\
\hline $\begin{array}{l}R \text {. cartagenesis Ali, } \\
\text { Riley and Self } 1985\end{array}$ & $6.1-6.9$ & $\begin{array}{l}196.6 \\
(190-200)\end{array}$ & $\begin{array}{l}321.6 \\
(315-325)\end{array}$ & $3.9-4.7$ & Colombia & $\begin{array}{l}\text { Gonatodes sp., } \\
\text { Hemidactylus sp. }\end{array}$ \\
\hline $\begin{array}{l}\text { R. chamaleonis } \\
\text { Gretillat and } \\
\text { Brygoo, } 1959\end{array}$ & $15-18$ & - & - & 6.5 & Madagascar & $\begin{array}{l}\text { Chamaeleo oustaleti } \\
\text { Mocquard, } 1894, \\
\text { C. verrucosus Blyth, } 1853\end{array}$ \\
\hline $\begin{array}{l}R \text {. morenoi } \\
\text { Abreu-Acosta, } \\
\text { Foronda Rodriguez, } \\
\text { Valladares and } \\
\text { Casanova, } 2005\end{array}$ & 25 & 309 & 401.7 & 5.7 & $\begin{array}{l}\text { Canary } \\
\text { Islands }\end{array}$ & $\begin{array}{l}\text { Gallotia atlantica } \\
\text { (Peters and Doria, 1882) }\end{array}$ \\
\hline R. mottae sp. nov.* & $7.2-7.8$ & $\begin{array}{l}222.5 \\
(224-226) \\
\end{array}$ & $\begin{array}{l}363.25 \\
(360-365) \\
\end{array}$ & $3.5-4.3$ & Brazil & Tropidurus hispidus \\
\hline
\end{tabular}

ao Desenvolvimento Científico e Tecnológico - FUNCAP (Ref. 943/03 - Edital 003/03). Thanks are also due to the Brazilian Institute for the Environment and Natural Resources - IBAMA for their permission to collect wild animal samples (080/04 - RAN/ IBAMA Processo 02007.001009/04-73); to Dr. Antônio Álamo Feitosa Saraiva (URCA), Mr. Samuel Vieira Brito and Mr. Felipe Silva Ferreira, for their help with our field work; to Dr. Breno Grisi, for suggestions and revision of the English version of the manuscript.

\section{References}

ABREU-ACOSTA, N., FORONDA RODRIGUEZ, P., VALLADARES, B. and CASANOVA, JC., 2005. Raillietiella morenoi sp. n. (Pentastomida) from Gallotia atlantica (Peters and Doria, 1882) (Lacertidae) in the Canary Islands. Parasitol. Res., vol. 98, no. 5, p. 425-429.

ALI, JH., RILEY, J. and SELF, JT., 1984a. A revision of the taxonomy of pentastomid parasites (genus Raillietiella Sambon, 1910) from American snakes and amphisbaenians. Syst. Parasitol., vol. 6, p. 87-97.

-, 1985. A review of the taxonomy and systematics of the pentastomids genus Raillietiella Sambon, 1910 with a description of a new species. Syst. Parasitol., vol. 7, p. 111-123.

ALMEIDA, WO. and CHRISTOFFERSEN, ML., 1999. A cladistic approach to relationships in Pentastomida. J. Parasitol., vol. 85 , no. 4 , p. 695-704.

-, 2002. Pentastomida, p. 187-202. In MORRONE, J. and LLORENTE-BOUSQUETS, J. (eds.), Biodiversidad, Taxonomía y Biogeografía de Artrópodos de México: Hacia una sintesis de su conocimiento, vol. 3. Universidad Nacional Autónoma de México, México, 690 p.

DIAS, EJR., VRCIBRADIC, D. and ROCHA, CFD., 2005. Endoparasites infecting two species of whiptail lizards (Cnemidophorus abaetensis and C. ocellifer; Teiidae) in a restinga habitat of northeastern Brazil. Herp. J., vol. 15, p. 133-137.

IPECE Instituto de Pesquisa e Estratégia Econômica do Ceará, 2005. Perfil básico municipal: Farias Brito. Governo do Estado do Ceará, Secretaria do Planejamento e Coordenação, Fortaleza.

MOTTA, CS., 1963. Considerações sobre o gênero Raillitiella Sambon, 1910. Atas Soc. Biol. Rio de Janeiro, vol. 7, no. 2, p. 8-10.

MOTTA, CS. and GOMES, DC., 1968. Sobre um novo gênero e uma nova espécie de Cephalobaenidae (Linguatulida, Cephalobaeniformia). Atas Soc. Biol. Rio de Janeiro, vol. 12, no. 1, p. 7-9.

REGO, AA., 1983. Pentastomídeos de répteis do Brasil: Revisão dos Cephalobaenidae. Mem. Inst. Oswaldo Cruz, vol. 78, no. 4, p. 399-411.

-, 1984. Sinopse dos pentastomídeos da região neotropical. Garcia de Orta, Série Zoologia, Lisboa, vol. 11, p. 45-46.

RILEY, J., 1986. The biology of pentastomids. Adv. Parasitol., vol. 25 , p. $45-128$.

-, 1993. Pentastomida, p. 293-307. In ADIYODI, K and ADIYODI, RG. (eds.), Reproductive biology of invertebrates. Vol. 6, Part B: Asexual propagation and 
reproductive strategies. New Delhi, Oxford and IBH Publishing Co. PVT.

RODRIGUES, MT., 1987. Sistemática, ecologia e zoogeografia dos Tropidurus do grupo torquatus ao sul do Rio Amazonas (Sauria, Iguanidae). Arq. Zool., vol. 31, no. 3, p. 105-230.

SELF, JT and KUNTZ, RE., 1967. Host-parasite relations in some Pentastomida. J. Parasitol., vol. 53, no. 1, p. 202-206.
VANZOLINI, PE., RAMOS-COSTA, AMM. and VITT, LJ., 1980. Répteis das caatingas. Academia Brasileira de Ciências, Rio de Janeiro, 161 p.

VRCIBRADIC, D., ROCHA, CFD., BURSEY, CD. and VICENTE, JJ., 2002. Helminth communities of two sympatric skinks (Mabuya agilis and Mabuya macrorhyncha) from two 'restinga' habitats in southeastern Brazil. J. Helmint., vol. 76, p. $355-361$. 
